\title{
SUMMARY OF THE 4TH GENERAL POLISH CONGRESS OF PARAMEDICS, KRAKOW, 13-15 OCTOBER 2016
}

\author{
Jerzy JASKUŁA \\ Military Institute of Aviation Medicine, Science Organization Division, Warsaw, Poland
}

Source of support: Own sources

Author’s address: J. Jaskuła, Military Institute of Aviation Medicine, Science Organization Division, Krasińskiego 54/56 Street, 01-755 Warsaw, Poland, e-mail: jjaskula@wiml.waw.pl

In October 2016, the Polish Congress of Paramedics was held for the fourth time at the Educational and Congress Centre of the Medical Faculty of the Jagiellonian University Medical College in Krakow. The scientific programme and a number of additional practical workshops placed the Congress at the forefront of Polish scientific events related to rescue and emergency medicine, especially in terms of the possibility of exchanging civil-military experience. The Military Institute of Aviation Medicine coorganised the event.

The Congress programme was divided into 9 thematic sessions: Paramedics - more rights, more duties, Daily practice of Emergency Medical Service Crews, Art of Education, Psychology and Clinical communication in paramedicine, EMS management, Event and mass events in the year of great events, Rescue in the sky, depths, tropics and travel, On the other side of the handset, i.e. dispatching in medical rescue and also From the battlefield to the ambulance - TCCC in the conditions of EMS and ER - Emergency Room.

The multidisciplinary approach to the issues related to the widely understood rescue services allowed participants to broaden their knowledge in the areas from education, through daily experience in the field of medical rescue operations, to issues related to the law, psychology, dispatching and management in rescue services. In addition, the programme of the Congress was extended with the subject of specialist

Full-text PDF: http://www.pjambp.com • Copyright @ 2016 Polish Aviation Medicine Society, ul. Krasińskiego 54/56, 01-755 Warsaw, license WIML • Indexation: Index Copernicus, Polish Ministry of Science and Higher Education 
rescue services and activities carried out outside the country's borders within the WIML session entitled "Emergency Response. Rescue in the sky, depths, tropics and travel". The session presented the subject of using helicopters as a means of medical evacuation in various climatic zones (Michał Madeyski, WIML), challenges for medical rescue in Kenya - (Anna Żądło, Polish Medical Mission), the role of the paramedic in securing high mountain expeditions (Maciej Stańczak) and the experience of medical teams on the battlefield (Alexandra Tomlinson-Nowak, US Army). In addition to the presentation of a representative of the American Army, the international nature of the Congress was also supplemented by a lecture by Colonel Ronald Ti of the Australian Armed Forces, entitled "Military Pre-Hospital Care-lessons learnt from a decade of deployments: The Australian Army experience" which was a collection of valuable experiences of the author's own experiences in providing medical assistance to wounded soldiers.

In the session on education and the session on rescue management, Jerzy Jaskuła (WIML) also lectured. The subject matter of the speeches included frequently committed errors in first aid education and results of clinical and systemic quality indicators research as an element of management in the National EMS System.
The "TRIAGE Krakow Rescue Service Group announcement of a new type of EMS team?", by Mr Piotr Kominek, also deserves distinction. The author described the first Polish experiences from the formation of a group of civilian paramedics, whose aim was to manage events with a large number of victims, medical segregation of many victims and cooperation with the Police in case of terrorist acts during mass events, which was reflected not only in the training programme of this group, but also in additional equipment with personal ballistic protection equipment.

In addition, as part of the Congress, practical workshops were held on, among others, the following issues: triage, conicotomy, modern methods of haemorrhage suppression, clinical communication, coping with stress, ultrasonography in emergency medicine and tactical and combat care of the injured on the battlefield.

4. National Congress of Paramedics allowed exchanging experiences, views and updating knowledge in the field of rescue and emergency medicine. This is an important element of professional training, both for paramedics working in the structures of the National EMS System (Polish EMS system) and medical personnel serving in the Armed Forces of the Republic of Poland. 